\title{
MICROBIOLOGICAL AND PHYSICAL PROPERTIES OF BEEF MARINATED WITH GARLIC JUICE
}

\author{
Nurwantoro, V. P. Bintoro, A. M. Legowo, L. D. Ambara, \\ A. Prakoso, S. Mulyani and A. Purnomoadi \\ Faculty of Animal Agriculture, Diponegoro University \\ Tembalang Campus, Semarang 50275, Central Java - Indonesia \\ Corresponding E-mail: nurwantoro.tehate@gmail.com
}

Received July 18, 2011; Accepted August 19, 2011

\begin{abstract}
The study was carried out to investigate the effect of marination, performed by soaking of beef in garlic juice, on microbiological and physical properties. The study was committed to a completely randomized design, with 5 treatments, i.e.: T0 (unmarinated beef, as a control), T1, T2, T3, and T4 that beef were marinated in garlic juice for 5, 10, 15, and 20 minutes, respectively, at room temperature $\left(25^{\circ} \mathrm{C}\right)$. Each treatment consisted of 4 replications. Examination upon experimental parameters was conducted after marinated (and control) beef was stored for 8 hours at room temperature. Total bacteria, total coliform and water holding capacity of beef were significantly $(\mathrm{P}<0.05)$ affected by marination with garlic juice. Conversely, cooking loss was not significantly affected $(\mathrm{P}>0.05)$ by the treatments. As a conclusion, marination of beef with garlic juice could reduce total bacteria, total coliform, and water holding capacity, but could not reduce cooking loss.

Keywords: beef, marination, garlic, microbiological properties, physical properties
\end{abstract}

\section{INTRODUCTION}

Beef is one of the animal-origin-foodstuffs that rich in valuable nutrients. The nutrients contained in beef are water (72.25-73.06\%), protein $(24.03-25.29 \%)$, fat $(3.91-4.40 \%)$, minerals (0.83-1.04\%), and a few of carbohydrate (Brahmantiyo, 2000). Due to its nutrients content, beef is a favorable medium for bacterial growth, therefore it becomes easily spoiled.

Bacterial contamination in beef begins from slaughterhouse. As reported by Sartika et al. (2005), beef obtained directly from slaughterhouses at Cibinong (Bogor regency) and Bogor city contained a significant amount of Escherichia coli. E.coli also contaminated by $60 \%$ of water samples collected from slaughterhouse, and $41.7 \%$ laborer who worked there. Arifin et al. (2008) reported that bacterial content of beef obtained from slaughterhouse in Semarang was $1.0 \times 10^{7} \mathrm{CFU} / \mathrm{g}$, while the number of bacteria in beef displayed at traditional market obtained from the same slaughterhouse was $1.2 \times 10^{8} \mathrm{CFU} / \mathrm{g}$.

Microbiological standard requirements upon beef circulating in Indonesia is $10^{6} \mathrm{CFU} / \mathrm{g}$ for total plate count (TPC), coliform bacteria is $10^{2}$
$\mathrm{CFU} / \mathrm{g}$, Staphylococcus aureus is $10^{2} \mathrm{CFU} / \mathrm{g}$, Salmonella sp. contained (per $25 \mathrm{~g}$ beef) should be negative, and E. coli should be $10 \mathrm{CFU} / \mathrm{g}$ (SNI $3932,2008)$. When the content of bacteria in beef exceeds these determined-standards, the beef is considered not recommended as food, due to its potential to be easily spoiled. The contaminated beef also potentially cause diseases when it is not processed (cooked) properly.

One method to process or preserve beef is marination. Marination is a process which meat is soaked in marinade-ingredients prior to further process (Smith and Young, 2007). Marinade is a seasoned solution that serves as substances for meat to be soaked. It is commonly used to increase meat yield, improve meat flavor, increase tenderness and juiciness, increase water holding capacity, lower cooking losses, and extend the shelf life of meat (Alvarado and Sams, 2003). Marination can be performed through soaking, injection, or tumbling (Alvarado and McKee, 2007). Processing of beef through marination also serves to lower bacterial content. One of the spices that may be used to marinate beef and at the same time as an anti-bacterial is garlic (Allium sativum L.). Garlic is often used as a seasoning in the processing of beef, and possibly can be used 
as a sole preservative (anti bacterial). Many studies reported that garlic could reduce the population of E. coli, Salmonella, Staphylococcus, Streptococcus, Klebsiella, Proteus, Bacillus, Clostridium, and Heliobacter pylory (Ress et al., 1993; Ankri and Mirelman, 1999; Sivam, 2001; Banarjee and Sarkar, 2003; El Astal, 2004). Garlic contains organo-sulfur compounds in the form of alliin and allicin. When garlic is crushed, the alliin reacts with the enzyme alliinase to form allicin in a few seconds (Ankri and Merelman, 1999). Allicin is a derived sulfur compound, provides a typical garlic aroma (smell) (Maidment et al., 2001). Pĕrez-Giraldo et al. (2003) reported that allicin with concentration of $4 \mathrm{mg} / \mathrm{ml}$ could inhibit the formation of biofilms (bacterial capsules) nearly $50 \%$ cultures of Staphylococcus epidermidis incubated 24 hours.

On the basis of reasons above, it was therefore of great interest to marinate beef with garlic juice using a soaking method. The purpose of this study was to investigate the effect of these treatments on microbiological features (total bacterial and total coliform) as well as physical properties (water holding capacity and cooking losses). The study was expected to provide information about beneficial effects of garlic as marinating ingredients, seasoning, anti-bacterial agent, as well as a substance that could improve the physical properties of beef.

\section{MATERIALS AND METHODS}

\section{Materials}

Materials used in this study were selected beef meat (shank) obtained from slaughterhouse in Semarang, and peeled garlic (water content of $65.48 \%$ ). Beef used in the study was collected from carcasses aged 2 hours post-mortem (withering process has not been completed yet). Medium used to calculate total number of bacteria was Nutrient Agar (NA), whereas Brilliant Green Lactose Bile Broth (BGLBB) was a medium used to count total coliform (Fardiaz, 1993). Nutrient Agar (brand Pronadisa) consisted of $3 \mathrm{~g}$ beef extract, $5 \mathrm{~g}$ peptone gelatin, $15 \mathrm{~g}$ agar and 1000 $\mathrm{ml}$ aquadest water, with $\mathrm{pH}$ 6.8. BGLBB (brand Merck) consisted of $10 \mathrm{~g}$ peptone, $10 \mathrm{~g}$ lactose, 20 $\mathrm{g}$ dried oxbile, $0.0133 \mathrm{~g}$ brilliant green, and 1000 $\mathrm{ml}$ aquadest water, with $\mathrm{pH}$ 7.2.

\section{Methods}

Experiment was conducted according to completely randomized design (CRD) consisted of 5 treatments and 4 replications. The treatments applied were T0 (unmarinated beef, as a control), $\mathrm{T} 1, \mathrm{~T} 2, \mathrm{~T} 3$, and T4 that beef was marinated with garlic juice for $5,10,15$, and 20 minutes, respectively, at room temperature $\left(25^{\circ} \mathrm{C}\right)$.

First stage of the study was making garlic juice by juicer producing an average yield of $40 \%$ with $\mathrm{pH}$ 5.90. Next stage was marination of beef by soaking the beef in garlic juice (according to treatment applied). Each replication used $100 \mathrm{~g}$ of beef. After being marinated, beef was drained for 10 minutes, put in glass bottles, and stored at room temperature $\left(25^{\circ} \mathrm{C}\right)$. Examination upon experimental parameters was conducted after marinated (and control) beef that was stored 8 hours at room temperature. Variables tested were total bacteria, total coliform, water holding capacity, and cooking losses of beef. Quantification of total bacterial was based on pour plate count method, while total coliform was quantified based on most probable number (MPN) method. Those methods were in accordance to National Indonesia Standard method (SNI 2897, 2008). Examination of water holding capacity and cooking losses were performed according to the method proposed by Soeparno (1994). Data obtained were analyzed using analysis of variance. A p-value of less than 0.05 was considered statistically significant. Duncan's Multiple Range Test was applied to assess significant statistical differences between means at 5\% level of probability (Steel and Torrie, 1990).

\section{RESULTS AND DISCUSSION}

\section{Microbiological properties of marinated beef}

The average total of bacteria and coliform in beef after being marinated with garlic juice can be seen in Table 1. The results showed that the time of marination (soaking) significantly affected $(\mathrm{P}<0.05)$ by the total bacteria and coliform in beef.

Marination of beef by soaking in garlic juice for 5-20 minutes led to a decrease of total bacteria and total coliform after 8 hours of storage at $25^{\circ} \mathrm{C}$. The decrease of total bacteria in marinated beef was most likely due to the acidic properties of garlic juice ( $\mathrm{pH}$ 5.90). Thus, marination of beef using garlic juice could be categorized as an acid marination that was intended to control or inhibit the growth of bacteria. Alvarado and McKee (2007) reported that marinating of meat with phosphoric acid salt resulted in lowered $\mathrm{pH}$ value, 
decreased water holding capacity, and controlled bacterial growth. Similar to the latter authors, Birk et al. (2010) reported that marinating of meat using organic acids might also inhibit bacterial growth. Low $\mathrm{pH}$ value is caused by the accumulation of hydrogen ions $\left(\mathrm{H}^{+}\right)$. Aritonang and Mihrani (2008) suggested that hydrogen ions which accumulate inside bacterial cell could be toxic; therefore it must be removed out. To eliminate the accumulation of hydrogen ions, bacteria need energy in the form of adenosine triphosphate (ATP). Thus, the higher hydrogen ions accumulated in the cell, the more ATP was needed to remove these ions out, as a result, the growth of bacteria became disrupted.

Garlic contains organo-sulfur compounds, namely alliin (S-allyl-cysteinesulphoxide) that is synthesized from amino acids cysteine. It is odorless and has no anti-microbial properties (Ankri and Mirelman, 1999). However, when garlic is crushed, alliin is immediately oxidized into allicin that has anti-bacterial properties (Maidment et al., 2001). This allicin could reduce cysteine contained in bacterial cells, so that it could disrupt disulfide bonds in bacterial proteins (Hernawan and Setyawan, 2003).

Based on the facts discussed earlier, it could therefore be concluded that the decrease of total bacteria and total coliform in marinated beef were the result of lowered $\mathrm{pH}$ value (acidic) and disrupted bacterial protein due to allicin. Our findings also suggested that soaking of beef in garlic juice for 15 minutes produced the best result. It was indicated by the total number of bacteria obtained, $6.7 \times 10^{5} \mathrm{CFU} / \mathrm{g}$, and the total coliform was $3.0 \times 10^{2} \mathrm{MPN} / 100 \mathrm{~g}$ or 3.0 or MPN/g. Referred to SNI 3932 (2008), total bacteria in beef should not exceed $10^{6} \mathrm{CFU} / \mathrm{g}$ and total coliform should be under $10^{2} \mathrm{CFU} / \mathrm{g}$.

\section{Physical properties of marinated beef}

The average of water holding capacity and cooking losses of beef after being marinated with garlic juice can be seen in Table 2. This study showed that the value of water holding capacity of beef were affected significantly $(\mathrm{P}<0.05)$ by the duration of soaking upon beef in garlic juice. Conversely, cooking losses of beef was not significantly affected $(\mathrm{P}>0.05)$ by the treatments.

The results showed that marinating of beef using garlic juice could decrease the water holding capacity. The decreased water holding capacity was assumed to be attributed to the decrease of $\mathrm{pH}$ value of beef due to the acidic properties ( $\mathrm{pH}$ 5.9) of garlic juice. The decrease value of $\mathrm{pH}$ in marinated beef was closely related to water holding capacity of beef. Water holding capacity is the ability of meat to bind water or added-water when any influences from outside force, such as: meat cutting, heating, milling, and pressure (Soeparno, 1994). Table 2 indicated that marinating of beef with garlic juice resulted in lowered water holding capacity compared to that

Table 1. Average of Total Bacteria and Total Coliform Contained in Beef Marinated with Garlic Juice

\begin{tabular}{ccc}
\hline Treatments & Total Bacteria $(\mathrm{CFU} / \mathrm{g})$ & Total Coliform $(\mathrm{MPN} / 100 \mathrm{~g})$ \\
\hline T0 & $1.2 \times 10^{7 \mathrm{a}}$ & $9.6 \times 10^{5 \mathrm{a}}$ \\
T1 & $4.4 \times 10^{6 \mathrm{ab}}$ & $9.2 \times 10^{2 \mathrm{~b}}$ \\
T2 & $6.5 \times 10^{6 \mathrm{ab}}$ & $5.8 \times 10^{2 \mathrm{~b}}$ \\
T3 & $6.7 \times 10^{5 \mathrm{~b}}$ & $3.0 \times 10^{2 \mathrm{~b}}$ \\
T4 & $6.6 \times 10^{5 \mathrm{~b}}$ & $3.0 \times 10^{2 \mathrm{~b}}$ \\
\hline
\end{tabular}

${ }^{\mathrm{a}-\mathrm{b}}$ Mean followed by different letters within the same column were statistically different $(\mathrm{P}<0.05)$

Table 2. Average of $\mathrm{pH}$ Water Holding Capacity and Cooking Losses of Beef Marinated with Garlic Juice

\begin{tabular}{crc}
\hline Treatments & Water holding capacity & Cooking losses \\
\hline T0 & $\ldots \ldots \ldots \ldots \ldots \ldots \ldots \ldots \ldots \ldots \ldots \ldots \ldots \ldots \ldots \ldots \ldots \ldots \ldots \ldots \ldots \ldots \ldots \ldots \ldots \ldots \ldots \ldots \ldots \ldots \ldots \ldots \ldots \ldots \ldots \ldots \ldots \ldots \ldots \ldots \ldots \ldots \ldots \ldots \ldots \ldots \ldots \ldots \ldots \ldots \ldots \ldots \ldots \ldots \ldots \ldots \ldots \ldots \ldots \ldots \ldots$ \\
T1 & $56.64^{\mathrm{a}}$ & 32.50 \\
T2 & $47.57^{\mathrm{b}}$ & 35.78 \\
T3 & $49.11^{\mathrm{b}}$ & 34.37 \\
T4 & $50.43^{\mathrm{b}}$ & 31.18 \\
& $51.40^{\mathrm{ab}}$ & 35.25 \\
\hline
\end{tabular}

${ }^{\mathrm{a}-\mathrm{b}}$ Mean followed by different letters within the same column were statistically different $(\mathrm{P}<0.05)$ 
of control (unmarinated beef). Alvarado and Sams (2003) suggested that marinating or soaking of beef in phosphate salt solution could lower $\mathrm{pH}$ value which in turn reduced water holding capacity and yield of beef. Water holding capacity decreased along with the decrease of $\mathrm{pH}$ value, from a high $\mathrm{pH}(7.00)$ to the $\mathrm{pH}$ of isoelectric point of meat proteins (5.10) (Purbowati et al., 2006). The decrease of water holding capacity was caused by the changes of $\mathrm{pH}$ of proteins actin and myosin that approached to isoelectric point after harvest (post-rigor). Post-rigor led to reduce space between protein filaments as well as reducing functional properties of proteins, consequently reducing water holding capacity of beef (Alvarado and McKee, 2007).

The results showed that cooking losses of beef was not affected significantly $(\mathrm{P}>0.05)$ by the different times of soaking of beef in garlic juice (Table 2). Cooking loss is the loss of weight or the shrinkage of meat due to cooking processes (Soeparno, 1994). Soaking of beef in garlic juice up to 5-20 minutes did not increase the yield of beef; perhaps, water from garlic juice was not optimally absorbed by the meat. This reason was most likely to convince why cooking losses of beef was not affected by marination. This result $\mathrm{s}$ were similar to that of reported by Wongwiwat $e t$ al. (2007). They reported that marination of chicken meat with various seasonings solution had no significant effect on tenderness (shear force) and drip loss of meat.

\section{CONCLUSION}

Marination of beef by soaking in garlic juice for 5-20 minutes could reduce total bacteria, total coliform, and water holding capacity of beef after being stored 8 hours in room temperature, but this treatment could not reduce cooking losses of beef. Soaking of beef in garlic juice for 15 minutes produced the best result since the content of total bacteria and total coliform fit to the provision required by SNI 3932 (2008).

\section{REFERENCES}

Alvarado, C. Z. and A. R. Sams. 2003. Injection marination strategies for remediationof pale, exudative broeler breast meat. Poult. Sci. 82:1332-1336.

Alvarado, C. Z. and S. McKee. 2007. Marination to improve functional properties and safety of poultry meat. J. Appl. Poult. Res. 16:113-120.
Ankri, S. and D. Mirelman. 1999. Antibicrobial properties of allicin from garlic. Microbes and Infect. 2:125-129.

Arifin, M., B. Dwiloka and D. E. Patriani. 2008. Penurunan kualitas daging sapi yang terjadi selama proses pemotongan dan distribusi di kota Semarang. Proc. Seminar Nasional Teknologi Peternakan dan Veteriner. Bogor, 11-12 Nopember 2008, p: 99-104.

Aritonang, S. N. and Mihrani. 2008. Pengaruh pencucian dengan larutan asam asetat terhadap nilai $\mathrm{pH}$, kadar protein, jumlah koloni bakteri, dan daya simpan daging ayam kampung pada penyimpanan suhu ruang. J. Agrisistem. 4:19-25.

Banerjee, M. and P. K. Sarkar. 2003. Inhibitory effect of garlic on bacterial pathogens from spices. World J. Microbiol. and Technol. 19:565-569.

Birk, T., A. C. Grønlund, B. B. Christensen, S. Knøchel, K. Lohse and H. Rosenquist. 2010. Effect of organic acids and marination ingredients on the suvival of Campylobacter jejuni on meat. J. Food Protect. 73:258-265.

Brahmantiyo, B. 2000. Sifat fisik dan kimia daging sapi Brahman Cross, Angus, dan Murray Grey. Media Veteriner. 7:9-11.

El Astal, Z. 2004. The inhibitory action of aqueous garlic extract on the growth of certain pathogenic bacteria. Eur. Food Res.Technol. 218:460-464.

Fardiaz, S. 1993. Analisis Mikrobiologi Pangan. Raja Grafindo Persada, Jakarta.

Hernawan, U. E. and A. D. Setyawan. 2003. Senyawa organo-sulfur bawang putih (Allium sativum L.) dan aktivitas biologinya. Biofarmasi. 1:65-76.

Maidment, D. C. J., Z. Dembny and D. I. Watts. 2001. The anti-bacterial activity of 12 Alliums against Escherichia coli. Nutrit. Food Sci. 31:238-241.

Pěrez-Giraldo, C., G. Cruz-Villalón, R. SánchezSilos, R. Martínez-Rubio, M. T. Blanco and A. C. Gómez-Garcia. 2003. In vitro activity of allicin against Staphylococcus epidermidis and influence of subinhibitory concentrations on biofilm formation. J. Appl. Microbiol. 96:709-711.

Purbowati, E., C. I. Sutrisno, E. Baliarti, S. P. S. Budhi and W. Lestariana. 2006. Karakteristik fisik otot Longissimus dorsi dan Biceps femoris domba lokal jantan yang dipelihara di pedesaan pada bobot potong yang berbeda. J. Protein. 33:147-153. 
Ress, L. P., S. F. Minney, N. T. Plummer, J. H. Slater and D. A. Skyrme. 1993. A quantitative assesment of the antimicrobial activity of garlic (Allium sativum). World J. Microbiol. and Biotechnol. 9:303-307.

Sartika, R. A. D., Y. M. Indrawani and T. Sudiarti. 2005. Analisis mikrobiologi Escherichia coli O157:H7 pada olahan hewan sapi dalam proses produksinya. Makara Kesehatan. 9:2328.

Sivam, G. P. 2001. Protection against Heliobacter pylori and other bacterial infection by garlic. J. Nutrit. 131:1106-1108.

Smith, D. P. and L. L. Young. 2007. Marination pressure and phosphate effects on broiler breast fillet yield, tenderness, and color. Poult. Sci. 86:2666-2670.

Soeparno. 1994. Ilmu dan Teknologi Daging. Gadjah Mada University Press, Yogyakarta.
Standard Nasional Indonesia (SNI 2897, 2008). Metode Pengujian Cemaran Mikroba dalam Daging, Telur, dan Susu, serta Hasil Olahannya. Badan Standardisasi Nasional (BSN), Jakarta.

Standard Nasional Indonesia (SNI 3932, 2008). Mutu Karkas dan Daging Sapi. Badan Standardisasi Nasional (BSN), Jakarta.

Steel, R. G. D. and J. H. Torrie. 1990. Principles and Procedures of Statistics. McGraw-Hill Book Company Inc., New York.

Wongwiwat, P., S. Yanpakdee and S. Wattanachant. 2007. Effect of Mixed Spices in Lemon Glass Marinade Decuisine on Changes in Chemical, Physical, and Microbiologycal Quality of Ready-to-cook Thai Indigenous Chiken Meat During Chilled Storage. Songklanakrin J. Sci. Technol. 29:1619-1632. 